\title{
Let's stick together? Explaining boundaries to territorial policy variation: the case of Germany's prisons legislation.
}

Carolyn Rowe (Aston) and Ed Turner (Aston)

\begin{abstract}
This paper offers an initial impact assessment regarding the introduction of new legislative responsibilities at the Land level in a case study of prisons policy (Strafvollzug). Combining an analysis of new legislation produced across the 16 Länder since the responsibility for prisons policy was transferred to the Land level, and insights into the mechanics of policy development obtained through a series of interviews with senior politicians and officials, this paper finds that the desire amongst Länder to legislative independently has varied, with substantial backing for co-ordination in the development of new legislation. This has helped to confound expectations of a 'competition of harshness' which many expected to result from decentralisation. However, even before the 2006 reforms, there were substantial variations between the Länder when it came to implementing prisons policy, so consideration of the sub-national level in this area remains essential.
\end{abstract}

\section{Introduction}

It has been widely argued that the sands of German federalism have shifted profoundly in the past three decades, particularly since reunification. ${ }^{1}$ Disparities between richer and poorer Länder have increased, and with this growing diversity have come pressures - in particular from wealthier Länder - for greater autonomy. One expression of these pressures was the decision in 2006 to pass responsibility for some areas of policy from the federal (national) government to the Länder. This development was also a response to demands for clearer lines of responsibility, and fewer areas of 'shared' responsibility between different tiers of government (bringing with them the possibility of legislative gridlock in the Bundesrat). ${ }^{2}$

In this contribution, we specifically assess the impact, some seven years since the reforms, of the decision to pass responsibility for prison legislation to the Länder. We aim to understand what impact passing legislative authority from the national to the Land level in Germany has had on prisons policy, and in particular the extent of any variation, and secondly to understand why policy has, or has not, diverged. This was - as will be illustrated below - a contentious change, vehemently opposed by many politicians, civil servants, and professionals working in the sector. In doing so, the aim is not merely to update our knowledge of the way in which German federalism operates, but also to contribute to our understanding of the effects which the decentralisation of responsibility for a particular area of policy might herald.

\footnotetext{
${ }^{1}$ E.g. Jeffery, Charlie (Ed. 2014), Recasting German Federalism. The Legacies of Unification, London: Pinter; Jeffery, Charlie / Rowe, Carolyn (2014) 'The Reform of German Federalism', in Padgett, S., Paterson, W. and Zohlnhoefer, R. (eds.) Developments in German Politics (4th edition), Basingstoke: Palgrave, pp.XXX .

${ }^{2}$ E. Turner / C. Rowe, "Party Servants, Ideologues or Regional Representatives? The German Länder and the Reform of Federalism”, West European Politics, (2013), 36/2, pp. 382-404
} 
Scholars and policy-makers alike are often seek to understand the impact of transferring power from one level of decision-making to another, and it is hypothesised that such a shift in responsibility brings with it particular consequences. Six potential impacts can be discerned from the relevant literature and are briefly set out below:

1. A commonly-expressed variant is that of a 'race to the bottom', whereby a shift in responsibility from a national to a sub-national jurisdiction will lead to downward pressure on levels of service provision, regulation or taxation, as the sub-national jurisdictions seeks to gain competitive or political advantages from offering lower levels of provision than their neighbours. ${ }^{3}$ For instance, Peterson's study of welfare benefits in the United States contends that 'To recommend that the provision of welfare should be locally controlled and its marginal cost borne by state and local taxpayers is to recommend that the poor be all but abandoned'. 4 He finds that states seek both to reduce spending on the politically unpopular project of welfare provision but also seek to avoid attracting recipients of benefits by having higher levels than those of their neighbours. Concerns about a 'race to the bottom' have also been associated with regulatory policy (for instance, environmental taxation) and corporate taxation, where states seek to lower regulation or taxation in order to attract businesses to their territory. ${ }^{5}$

2. An alternative variant is a 'race to the top', whereby levels of service provision or regulation will increase following decentralisation. There are two mechanisms which may prompt such a 'race'. The first is where provision of a good is politically popular, so states compete to offer the greatest level of service - an effect which may be heightened where feelings of solidarity are greater within smaller jurisdictions, thus legitimising higher levels of service provision. ${ }^{6}$ The second mechanism relates to regulatory policy, whereby manufacturers based in a larger, powerful jurisdiction with higher levels of regulation will lobby for smaller jurisdictions to raise their regulation to the same level, to avoid any disadvantage vis-à-vis companies based in the smaller jurisdiction. ${ }^{7}$

3. A 'race to the middle' scenario may occur, whereby states seek to avoid being outliers, and use levels of service provision, regulation or taxation in other states as a benchmark. ${ }^{8}$

\footnotetext{
${ }^{3}$ E.g. Oates, Wallace E (1972): Fiscal Federalism (New York: Harcourt Brace Jovanocich).

${ }^{4}$ Peterson, Paul E. (1995): The Price of Federalism (Washington: Brookings Institution).

p. 128.

${ }^{5}$ Wilson, John D. (1996) "Capital Mobility and Environmental Standards: Is There a Theoretical Basis for a

Race to the Bottom?", in Bhagwati, J and Hudek R (eds.), Harmonization and Fair Trade, volume 1

(Cambridge, MA: MIT Press), pp. 395-427..

${ }^{6}$ Keating, Michael (2009), "Social Citizenship, Solidarity and Welfare in Regionalized and Plurinational States", in Citizenship Studies, 13/5, pp. 501-513.

${ }^{7}$ Vogel, David / Kagan, Robert A. (2004): "Introduction: National Regulations in a Global Economy", in Vogel, David / Kagan, Robert A.: Dynamics of Regulatory Change: How Globalization Affects National Regulatory Policies (Berkeley: University of California Press), pp. 1-41.

${ }^{8}$ Green, David A / Harrison, Kathryn (2006): 'Races to the Bottom versus Races to the Middle: Minimum Wage Setting in Canada', in Harrison, Kathryn (Ed.): Racing to the bottom? Provincial Interdependence in the Canadian Federation (Vancouver: UBC Press), pp. 193-228.
} 
4. The 'laboratories of democracy' scenario, whereby states use new policy freedoms to experiment, and then compare and learn from each other, leading to diffusion of good practice, and avoidance of choices which have not proved their worth.

5. The 'parties matter' scenario, whereby variations in policy will be driven by the composition of the government at the state level. So for instance, a conservative government might use new flexibility in education policy to increase the level of selection in education, or a left-wing state government could increase spending on social programmes. ${ }^{9}$

6. The 'policy response to context' scenario, whereby policies are adapted to 'fit' particular features of the state context. ${ }^{10}$ For instance states with conservative-minded populations might be expected on this analysis to adopt restrictive rules on the wearing of headscarves, while those with a particular problem of long-term unemployment would adapt labour market policy to focus on this particular group.

There is, however, an alternative, which is that even after a shift in responsibility from the national level to the state level, policies do not change, and states do not take advantage of their new ability to introduce variation. There are various ways this might be driven:

1. By path dependence, whereby existing policies have built up support from public expectation or institutions able to defend the status quo, or more broadly where the costs of change outweigh any potential benefit. ${ }^{11}$

2. By the absence of any of the above-mentioned drivers of policy variation (such as different political parties having different views, or differences in context).

3. By a commitment to consistency of policy across the territory, either for normative reasons (a rejection of apparently arbitrary instances of inconsistency termed a 'postcode lottery' in the UK), or because variation would be feared to bring with it particular costs. Examples of such costs might be confusion for consumers, as Reus notes was a concern in the case of smoking bans, or undermining the mutual recognition of qualifications across the territory, which is a frequent anxiety when federalism in the German education system is discussed. ${ }^{12}$

Prisons policy offers several benefits as a case study in the impact of decentralisation. First, it represents a clear transition of legislative authority: prior to the 2006 reforms, policy on prisons was exclusively a matter for the national government (although, typically in the German context, the Länder were responsible for policy implementation, namely the running of prisons as well as the issuing of relevant regulations). Thereafter, sole responsibility transferred to the Länder,

\footnotetext{
${ }^{9}$ Schmidt, Manfred G (1980): CDU und SPD an der Regierung: Ein Vergleich ihrer Politik in den Ländern (Frankfurt: Campus). Turner, Ed (2011): Political Parties and Public Policy in the German Länder: When Parties Matter (Basingstoke: Palgrave Macmillan).

${ }^{10}$ E. Turner, Political Parties, J. von Blumenthal, Das Kopftuch in der Landesgesetzgebung: Governance im Bundesstaat zwischen Unitarisierung und Föderalisierung (2009, Nomos: Baden Baden).

11 Pierson, Paul (2000): 'Increasing Returns, Path Dependence, and the Study of Politics', in American Political Science Review, Vol. 94/2, pp. 251-267.

12 Reus in this volume.
} 
subject to conformity with the German Basic Law (constitution) and the European Convention on Human Rights. Secondly, it is an area of some political controversy, with long-standing debates between 'hardliners' and 'liberal reformers'. Therefore, several of the possible policy developments alluded to above (such as competition to gain a political advantage by differentiating policies from neighbours, or divergence along partisan lines) might be expected. Thirdly, it is useful precisely because much of the literature on the impact of decentralisation (as cited above) focuses on matters of regulation, taxation, or public expenditure on welfare entitlements and lessons have been drawn accordingly; it will be an excellent test of propositions developed for these policy areas to see whether they also stand up in an area which does not fit into these categories.

This study draws upon four sources of evidence. Laws on prisons, youth prisons, and investigative detention were collated for each of the sixteen Länder, and compared. Second careful review of secondary literature, not only in academic texts and scholarly journals but also in the (highly useful) publication of the professional association of prison professionals, was conducted. Thirdly, expert interviews were conducted with relevant actors in five Länder (with a mixture of larger and smaller, richer and poorer, Christian Democrat-led and Social Democrat-led, and eastern and western), including politicians and civil servants, namely Bavaria, SchleswigHolstein, Rhineland Palatinate, Thuringia and Berlin. Parliamentary debates on proposed legislation in these cases were also examined.

The remainder of this paper is structured as follows. The next section provides a brief exposition of the context of German prisons legislation prior to the 2006 federalism reform. Section three offers an account of the decision to transfer responsibility for prisons legislation from the federal government to the Länder. Section four presents the substantive findings, considering in turn laws on youth prisons, adult prisons and investigative detention. Section five concludes- finding that variations in prisons legislation, while present, are more limited than was anticipated at the time of the reform, and with little evidence of the much-feared 'race to the bottom'. In no small measure, this is due to a clear normative commitment to avoid arbitrary policy variation amongst politicians, and in particular civil servants, involved. However, there is substantial variation in the way prisons law is implemented in Germany, making scrutiny of what happens below the national level an important exercise.

\section{Prisons policy in Germany prior to 2006}

For much of the post-War period, there was no specific legislation governing the operation of prisoners and the treatment of prisoners. Certain basic rights, starting with, in Article 1, the inviolability of human dignity, were enshrined in the Basic Law, which stated that these rights might only be modified in primary legislation, and that their essence could never be altered (Article 19). However, it was initially accepted that some groups - such as minors, members of the armed forces, and prisoners - 
were in a 'special authority relationship' to the state, and so their rights could indeed be restricted without primary legislation. ${ }^{13}$

However, by the early 1970s the Federal Constitutional Court had twice stepped in to require a change of track. In 1972, in a case on prisoners' right to receive post, the Court ruled that 'Basic rights of prisoners may only be restricted by or on the basis of a law' and '... could only be considered when they are essential for the achievement of an aim of the community as specified in the Basic Law'. ${ }^{14}$ In 1973, flesh was put on these bones, in the Lebach judgement (concerning the right of a prisoner not to be named and pictured in a television documentary about his crime), which ruled that resocialisation of offenders had to be the primary objective of the implementation of prison sentences. ${ }^{15}$

The government at the time - the Social-Liberal (SPD-FDP) coalition under Chancellor Helmut Schmidt and Justice Minister Hans-Jochen Vogel - responded with the Federal Prisons Law of 1976, which not only required the aim of imprisonment to be to 'enable the prisoner to lead a socially responsible life without committing criminal offences', but also provided a detailed framework for the operation of prisons, covering such matters as day release, post, work and pocket money.

Nonetheless, as Vogel himself observed in an interview in 1974, many important matters in the operation of prisons were questions of implementation, and solely the responsibility of the Länder: as he put it, 'The law is not a panacea ... in the 186 prisons, not even the planned 143 doctors' posts are actually filled, and there are major gaps in [other] personnel. Here the national government cannot offer any immediate assistance. The competence for this has been given by the Basic Law exclusively to the Länder'. ${ }^{16}$ A critical commentary half a decade later observed that provisions in the new law had been 'simply ignored', for instance concerning the level of pay for prisoners' work, their enrolment in social insurance, and the availability of social therapy. ${ }^{17}$

In 2006, and therefore prior to the federalism reform, scholars discerned substantial variations between the Länder in the implementation of prisons policy, notwithstanding the common legal framework. In an essay entitled 'Prisons policy as Land responsibility? The "competition of harshness" is already happening', Dünkel and Schüler-Springorum compare data in a range of areas, and find substantial variations across Germany. In 2004, 32\% of prisoners were in open prisons in Berlin, compared to $6.4 \%$ in Thuringia and $7.8 \%$ in Bavaria. In the same year, 820 agreed absences from prison per 100 prisoners were agreed in the Saarland, compared to 66.7 in Saxony-Anhalt. While $15.7 \%$ of prisoners in Hamburg had to share a cell, $78.6 \%$ were required to do so in Thuringia. ${ }^{18}$ Some of these differences

\footnotetext{
${ }^{13}$ F. Dünkel and D van Zyl Smit, 'The Implementation of Youth Imprisonment and Constitutional Law in Germany', Punishment \& Society 9/3 (2007), pp. 347-69, here p. 348-50.

${ }^{14}$ Bundesverfassungsgericht, Judgement of 14.03.1972, 2. BvR 41/71.

${ }^{15}$ Bundesverfassungsgericht, Jugement of 05.06.1973, 1. BvR 536/72.

${ }^{16}$ Die Zeit, 30 August 1974, 'Dampf in der Debatte: Ein Zeitgespräch mit Bundesjustizminister Hans-Jochen Vogel', p.3.

${ }^{17}$ Der Spiegel, 25 October 1982, 'Dreizehn Jahre geliehene Macht', pp. 81-100.

${ }^{18}$ F. Dünkel / H. Schüler-Springorum, 'Strafvollzug als Ländersache? Der "Wettbewerb der Schäbigkeit" ist schon im Gange!', Zeitschrift für Strafvollzug und Straffälligenhilfe 3 (2006), pp. 145-9.
} 
could be accounted for by differences between eastern and western Länder (with different histories and also prison infrastructure) but by no means all. Interviews with practitioners confirmed that - while analysis of the legal framework concerning prisons would be useful in and of itself, this only gives an incomplete picture of what actually happens within the walls of prisons in Germany. ${ }^{19}$

Meanwhile, there was no particular legal framework concerning youth prisons, in spite of calls for primary legislation from the expert Commission on Youth Imprisonment, and various proposals from the Federal Ministry of Justice throughout the 1980 s and 1990s (which were blocked by the majority of Länder). ${ }^{20}$ Instead, the 1976 law was considered to apply also to youth detainees.

In summary, then, for the period from the foundation of the Federal Republic of Germany until 2006, there was a common national legal framework concerning prisons, first provided in very general terms by the Basic Law, then by certain Federal Constitutional Court Verdicts, and from 1976 onwards by the Federal Prisons Law. However, there were significant variations between the Länder in the way in which this law was implemented, thus reinforcing the view that territorial variation in Germany is more prevalent than is often assumed to be the case. ${ }^{21}$

\section{Discussion of prisons policy in the 2006 reform}

The decision to make prisons the exclusive competence of the Länder proved highly controversial, and critics argued that it lacked any sound rationale: while there might be some operational pressures leading to policy differentiation (such as the availability of open prison places), these would not require a different legal basis in each Land. As noted above, such variations existed already - rather to the regret of professionals - in spite of the common federal law. The phrase "competition of harshness" (Wettbewerb der Schäbigkeit) was often used by critics of the measure, who felt that Länder would out-bid each other in terms of being seen to punish prisoners, and also release funds for more popular purposes than serving prisoners' needs. This would indeed be a variation of downward competitive pressure, or 'race to the bottom', identified in the introduction.

The federalism reform commission, which ran from 2002 to 2004, did not appear to consider a shift in responsibility for prisons law to the Länder for most of its deliberation, and the proposal only surfaced in late 2004, even though it had been explicitly rejected by the Länder only months before. ${ }^{22}$

Only limited reasons in favour of the transfer can be discerned from relevant parliamentary debates. Minister Wolfgang Reinhart from Baden-Württemberg argued that, as the Länder were responsible for paying for prisons, so the Länder should be responsible for the rules financing them. ${ }^{23}$ Bavaria's Minister President,

\footnotetext{
${ }^{19}$ Interview with recent governor of youth prison, Berlin, 17 October 2012.

${ }^{20}$ Dünkel and van Zyl Smit, 'The Implementation of Youth Imprisonment', p. 351.

${ }^{21}$ Jeffery Pamphillis etc JEPP.

${ }^{22}$ Schneider, Hans-Peter (2013), Der neue deutsche Bundesstaat: Bericht über die Umsetzung der

Föderalismusreform I (Nomos: Baden-Baden), pp. 220-2.

${ }^{23}$ Bundesrat Protokoll, $7^{\text {th }}$ July 2006, p. 221.
} 
Edmund Stoiber, thought that debates on prisons policy would attract greater public attention if held in the Land parliaments, ${ }^{24}$ and Roland Koch from Hesse enthused about opportunities for policy experimentation, in an area where Germany had not distinguished itself. ${ }^{25}$ Peter Struck, the Parliamentary Leader of the SPD, appeared to justify the transfer of responsibility as a quid pro quo, which had not been wanted by his side, and something he would watch, to see there was not a 'race to the bottom'. 26 Chancellor Angela Merkel referred obliquely to the desire to strengthen Land parliaments and subsidiarity. ${ }^{27}$

A more plausible explanation for the shift emerged in interviews with protagonists. ${ }^{28}$ There was intense frustration amongst some Länder, in particular Bavaria (and also to a degree the federal government), that it had proven impossible to reform prison law, with changes - such as hardline modifications put forward by Hesse, which would weaken the emphasis on rehabilitation of prisoners as a purpose of punishment - failing to find a majority, as Länder led by the SPD were opposed. ${ }^{29}$ Indeed, the same gridlock had been observed, in matters of youth justice, when the federal governments' attempt at laws had been blocked (mostly on grounds of cost) by the majority of Länder in the Bundesrat on no fewer than four occasions in the 1980s and 1990s. ${ }^{30}$ Thus, the shift of power from the national level to the Länder had much more to do with a desire to reduce the need for agreement by a majority of the Länder in the Bundesrat, and the federal parliament, than with functional or popular pressures for variation across the German territory.

Nonetheless, there was a great deal of anger expressed at the changes. A letter from twelve former ministers of justice, endorsed by the association of German judges, objected to inconsistency that would arise between different parts of the judicial process at different levels of government. ${ }^{31}$ An editorial in the Zeitschrift für Strafvollzug, a journal of prisons professionals, objected to a "fracturing" of prison law. It pointed to the difficulty co-operation between Länder in accommodating particular groups if they had different prison laws; the difficulty of moving prisoners for security reasons from one Land to another, and the apparent injustice of two prisoners from different parts of Germany being arrested for a crime in Berlin, but being treated very differently when returned to their local Land on account of different laws there. ${ }^{32}$

There was substantial opposition in both chambers of the legislature. In the Bundestag, the Green MP Wolfgang Wieland called the lack of attention paid to

\footnotetext{
${ }^{24}$ Bundesrat Protokoll, $7^{\text {th }}$ July 2006, p. 205.

${ }^{25}$ Bundesrat Protokoll, $7^{\text {th }}$ July 2006, p. 214.

${ }^{26}$ Bundestag Protokoll, $30^{\text {th }}$ June 2006, p. 4240.

${ }^{27}$ Bundestag Protokoll, $30^{\text {th }}$ June 2006, p. 4258.

${ }^{28}$ Interview, Bavarian negotiator, $5^{\text {th }}$ December 2013.

${ }^{29}$ Die Welt, "Hessen fordert Wende zu mehr Härte beim Strafvollzug", $25^{\text {th }}$ February 2003.

${ }^{30}$ Duenkel / Van Zyl Smit p.351.

31 "Deutscher Richterbung unterstützt Appell ehemaliger Justizminister gegen Verlagerung der Gesetzgebungskompetenz für den Strafvollzug", Press Release, Deutscher Richterbund, $17^{\text {th }}$ February 2006, available at http://www.drb.de/cms/index.php?id=81 (last consulted 3 June 2014).

${ }^{32}$ U. Kopp, 'Keine Verlagerung der Gesetzgebungskompetenz für den Strafvollzug auf die Länder Gesetzgebungskompetenz für den Strafvollzug muss beim Bund bleiben', Zeitschrift für Strafvollzug und Straffälligenhilfe 1(2006), p. 3.
} 
expert warnings "shameful and shocking", ${ }^{33}$ while the former Federal Justice Minister and senior Liberal politician, Sabine Leutheusser-Schnarrenberger, said that the move was the "wrong step", and that it could lead to the deletion of resocialisation as the aim of imprisonment. ${ }^{34}$ In the Bundesrat, similarly, several representatives of the Länder opposed the measure, with Erwin Sellering (from Mecklenburg Lower Pomerania), stating that it would be the end of "equality before the law", ${ }^{35}$ and Ralf Stegner from Schleswig-Holstein, fearing a "competition of harshness".

Notwithstanding opposition from the Greens and Left Party, limited breakdown in party cohesion amongst members of the ruling grand coalition (with many more harbouring private reservations), and near-universal condemnation from prisoners professionals, the transfer of responsibility for prisons laws was indeed agreed in 2006. Heribert Prantl, a prominent commentator and prison reformer, dismissed reassurances that the Federal Constitutional Court would be able to keep unwarranted differential at bay, stating that:

"In practice, the new situation will be uncontrollable for the highest court. Prison walls will get higher, and Karlsruhe [home of the Federal Constitutional Court] will be far away. Even today, between aims and reality of prison lie increasing incarceration rates and overcrowding of prisons. ... [The reform] is a grave, historical mistake". ${ }^{36}$

\section{Results: the impact of the 2006 federalism reform on prisons policy}

This section summarises the findings of our analysis of laws on prisons on the 2006 reform. We consider, firstly, laws on youth prisons (where legislation was passed in each Land as a result of a Federal Constitutional Court verdict), then laws on adult prisons, insofar as these exist, and finally provide a brief discussion of investigative detention. In each case, we highlight differences between laws - insofar as they exist - but also account for similarities, based upon our interviews with actors (politicians, civil servants, and practitioners) in the field.

\section{Youth prisons}

As noted above, until 2006 there was no separate legislation concerning youth prisons in Germany, and instead these came under the Federal Prison Law. Such a situation had long been criticised by experts - in particular reformers - and in 2006, the Federal Constitutional Court ruled that youth imprisonment required its own basis in primary legislation, in order to meet the particular requirements of young people. ${ }^{37}$ Thus, the Länder needed to act, and act quickly, in order to resolve this situation the Court set a deadline of the end of 2007 for them to comply.

There were three different reactions amongst the sixteen Länder. In three cases, Bavaria, Lower Saxony, and Hamburg (each of which were led by Christian

\footnotetext{
${ }^{33}$ Bundestag Protokoll, $30^{\text {th }}$ June 2006, p. 4261,

${ }^{34}$ Bundestag Protokoll, $30^{\text {th }}$ June 2006, p. 4269.

${ }^{35}$ Bundesrat Protokoll, $7^{\text {th }}$ July 2006, p. 220.

${ }^{36}$ H. Prantl, "Das Hexeneinmaleins des Strafvollzugs", Forum Strafvollzug 1(2007), p. 22.

${ }^{37}$ Dünkel and van Zyl Smit, 'The Implementation of Youth Imprisonment', p. 351.
} 
Democrats), new Prisons Laws were created, with its own section on youth prisons. In a further four cases (North-Rhine Westphalia, Hesse, Baden-Württemberg and Saxony - again all led by Christian Democrats) separate youth prisons laws were created. The remaining nine Länder (including all the ones led by Social Democrats) decided to cooperate at the level of civil servants, and work on a Musterentwurf (a model draft of legislation), which could then be agreed to, subject to any variations wanted by the Land parliament, in each Land. ${ }^{38}$

In terms of process, there was thus a clear difference between those Länder which wanted to use their new found opportunity to formulate their own, distinctive new law, and those who committed to collaborate with other Länder on new laws, in a process which would, necessarily, keep differences to a minimum. Since Christian Democrats had been distinctly more enthusiastic about decentralising this policy area than their Social Democratic counterparts, it should be no surprise that only Christian Democrat-led Länder chose to develop their own laws, with each SPD-led land becoming involved in the Musterentwurf process. As the CSU's prisons spokesperson said "What's the point of having a federalism reform, if you then have a Musterentwurf?"39 Of course, there would be every point if the principle of the federalism reform, with a desire to allow diversity in the legal framework, was not accepted. It is also worth noting that the larger Christian Democrat-led Länder (such as Bavaria, Baden-Württemberg, Lower Saxony, Hesse, and North-Rhine Westphalia) went their own way, while most of their smaller counterparts (such as Saxony-Anhalt and the Saarland) chose to co-operate. This could point to different levels of capacity in drafting legislation, appetite to plough their own policy furrow, or indeed pressure to cooperate in day-to-day prisons policy with neighbours.

The process of drawing up the Musterentwurf was led by civil servants - generally, but not necessarily, the Director (Abteilungsleiter) in the Ministry. To a degree, even Länder not formally part of the process took an interest. Crucially, politicians only became involved at the very end of the process, when the Musterentwurf went to Justice Ministers for any amendments prior to presentation to the Land's cabinet and then parliament. Thus, dominance of the executive (sometimes a feature of decision-making in the Bundesrat which generated disapproval) was reinforced. It might have been expected that the Musterentwurf process would save time for each Land, but a participant interviewed suggested the opposite was the case - it took longer, but led to greater rigour and probing of possible consequences, as well as a more co-ordinated outcome. ${ }^{40}$ A Social Democratic politician suggested in an interview that working from a Musterentwurf also bought a party political benefit, as criticisms from the CDU opposition could be dismissed with a reference to the fact that some Christian Democrat Länder had identical provisions in their own laws. ${ }^{41}$

On the substance of the laws, we identify five particular areas of difference between the laws, setting out the major differences between them. These dimensions are

\footnotetext{
${ }^{38}$ In fact, Saxony was initially part of the Musterentwurf process, but dropped out, apparently as it did not want to fund the pocket money it would have needed (interview with civil servant, 5 November 2012).

${ }^{39}$ Interview with Land politician, $3^{\text {rd }}$ December 2013.

${ }^{40}$ Interview with civil servant, $5^{\text {th }}$ November 2012.

${ }^{41}$ Interview with Land politicians, $7^{\text {th }}$ November 2012.
} 
amongst those considered in existing expert analyses. ${ }^{42}$ They are based on our own analysis of the laws passed. ${ }^{43}$

Aims of punishment: As discussed above, Hesse had previously attempted to redefine the aims of punishment, so that protection of the community would have greater prominence, rather than resocialisation of offenders. However, the Federal Constitutional Court verdict of 2006 set rather strict parameters in this regard, by making it clear that only by resocialisation could the community be protected. ${ }^{44}$ Two Länder, Bavaria and Hamburg, identify two functions of youth prison, namely protection of the community - which is mentioned first in both cases - and resocialisation of offenders. Baden-Württemberg follows a similar logic (though they are a long way apart in the legal text, and it is not immediately clear which has priority). Lower Saxony emphasises the equivalence of resocialisation and protection of the community, while the remaining Länder (Hesse, North-Rhine Westphalia, Saxony and those signed up to the Musterentwurf) all gave primacy to the aim of resocialisation, while giving 'protection of the community' equivalence as a function. This was, therefore, an area where some - but only some - Christian Democrat-led Länder chose deliberately to 'fly a conservative flag'. ${ }^{45}$

Entitlement to single cells: In all Land laws, there is some level of commitment to providing prisoners with single cells (considered important in particular in the context of a murder in Siegburg youth prison in 2006). ${ }^{46}$ However, in each case there are opportunities for this not to be observed, either where a shared cell is in the prisoner's interest (e.g. fears for the prisoner's health), or temporarily for other operational reasons. In most Länder, though, single cells must otherwise be offered. There are four variations upon this line: Bavaria has a substantially weaker entitlement to a single cell, under which prisoners 'should' have a single cell, rather than this being a requirement; Baden-Württemberg and Hamburg also state that prisoners 'should' have a single cell, but with more exceptions under which a single cell must be offered (in the former case, in new prisons single cells must be offered, in the latter, exceptions from when prisoners 'should' be offered a single cell are more limited). In Berlin, the legislation set a deadline of the end of 2012, after which 'operational reasons' would no longer justify a breach of the requirement for single cells. Again, in this area, we see party politics appearing to play a role, with some CDU-led Länder offering less generous provisions for prisoners, and a slightly more liberal line being taken by the SPD-Left Party coalition in Berlin.

\footnotetext{
42 T. Höynck, N. Hagemann, B.-M. Kapteina, K. Klimaschewski, V. Lübke, N. Luu, F. Riechey, 'Jugendstafvollzugsgesetze der Länder: Eine Auswahl wichtiger Regelungsbereiche in synoptischer Darstellung', Zeitschrift für Strafvollzug und Straffälligenhilfe. 57(2/2008): pp. 159-66; J. Feest / K. Bammann, 'Jugendstafvollzugsgesetze: Anspruch und Umsetzung', in B. Dollinger / H. Schmidt-Semisch (eds, 2010), Handbuch Jugendkriminalität: Kriminologie und Sozialpädagogik im Dialog (Wiesbaden: VS Verlag), pp. 53543; Ostendorf, H. (Ed, 2012, $2^{\text {nd }}$ edition): Jugendstafvollzugsrecht: Kommentierte Darstellung der einzelnen Jugendstrafvollzugsgesetze (Baden-Baden: Nomos); F. Dünkel / A. Pörksen, 'Stand der Gesetzgebung zum Jugendstafvollzug und erste Einschätzungen', Neue Kriminalpolitik (2/2007), pp. 55-67.

${ }^{43}$ A comprehensive collection of all laws is available in Handbuch Strafvollzug der Länder 2013/14

(Regensburg: Walhalla Verlag).

${ }^{44}$ Feest / Bammann, 'Jugendstrafvollzugsgesetze', p. 536.

${ }^{45}$ Feest / Bammann, 'Jugendstrafvollzugsgesetze', p. 537.

${ }^{46}$ Dünkel / Pörksen, 'Stand der Gesetzgebung', p. 60
} 
Open and closed prisons: This is another area where there is some variation in the new laws. In the Musterentwurf, and in the laws of Saxony and North Rhine Westphalia, open and closed prisons are presented as equal options. North Rhine Westphalia goes further with its endorsement of open prisoners, with a requirement to move a prisoner to an open prison if it is appropriate; in the other cases, a prisoner "should" be transferred if appropriate. By contrast, and with slightly different formulations, Hamburg and Hesse give priority to closed prisons, while noting that a prisoner "can" be moved to an open prison under some circumstances; Bavaria and Lower Saxony also have as a default closed prisons, but prisoners "should" move to an open prison if appropriate. Baden-Württemberg's law also contains a difference: the Land had adopted a pilot of youth custody, whereby it would occur in an institution run by youth services, and this is explicitly referred to in the Land's law alongside open and closed prisoners. With the exception of Bavaria, and Hamburg, each of the Länder also refers to this possibility, while affording it less prominence. So here we again appear to see a party political pattern, with some CDU/CSU-led Länder adopting more 'hardline' laws, but we also see regional path dependence, since Baden-Württemberg chose to reflect its (successful) experience with alternative forms of detention in its law.

Accommodation in living groups (Wohngruppen): In youth prisons, it was often felt that accommodating prisoners in small groups where they would spend their time (when not in individual cells) was desirable, and the initial draft law from the Federal Justice Ministry specified this as being what should happen 'regularly'. A maximum size of these groups was, in that draft, set at eight prisoners. There is now some variation in the extent to which this model finds endorsement in the laws of the Länder. The Länder following the Musterentwurf, and also Saxony and Hesse, stuck with the formulation proposed by the federal justice ministry, albeit without stating the maximum group size (apparently at the request of Land finance ministries), except in the case of Hesse (which followed the Federal Justice Ministry's proposal on size). ${ }^{47}$ Baden-Württemberg, Lower Saxony, and Hamburg used a weaker formulation, stating that suitable prisoners 'should' be accommodated in living groups. Hamburg also mentions a minimum size of 8 , and maximum of 15 prisoners. Bavaria has the weakest formulation, stating that 'appropriate' prisoners 'can' be accommodated in living groups.

Access to therapy: All the Land laws refer to the possibility of access to therapy while serving their sentences, but there are variations in the extent to which each prisoner has a legal entitlement to it. In most Länder, laws state that prisoners 'can' be accommodated in a social therapy institution; however, this is stronger in Rhineland-Palatinate, where the draft law was amended by parliamentarians to say that prisoners 'should' have an entitlement to therapy; in Bavaria, Hamburg and Lower Saxony, there is a legal requirement to provide therapy in certain circumstances.

The details given above refer to the laws at the time they were passed; clearly, legislators may undertake amendments from time to time (and indeed some Länder have now included youth prisons in revised prison laws). The revisions in Hamburg have, however, been particularly interesting. In 2008, it held an election in which the

${ }^{47}$ Dünkel / Pörksen, 'Stand der Gesetzgebung', p. 62. 
CDU, which previously had an overall majority, lost ground and needed to form a coalition. It did so with the Green Party / Alternative List, and the Greens then took control of the Ministry for Justice. A new law on prisons swiftly followed, which led to a more liberal line being taken on such issues as open prisons (to which appropriate inmates 'should' be transferred) and entitlement to single cells. ${ }^{48}$

In summary, then, there are three conclusions that can be drawn in relation to youth prisons laws. First, the laws are in essence quite similar, with only limited areas of substantial difference; this is particularly the case, unsurprisingly, where Länder chose to co-operate on drawing up the new law. Secondly, what differences there were often appear attributable to party politics, with some, but only some, Christian Democrat Länder keen to put down a conservative marker. In Hamburg, such markers were promptly reversed when the Green Party took over the justice ministry. Thirdly, as in the case of Baden-Württemberg's provision for alternative provision of youth custody other than in a prison, Land-specific factors shaped the laws to a limited degree.

\section{Adult prisons}

At the time of writing, not all Länder had produced an adult prison law. As noted above, Bavaria, Baden-Württemberg, Lower Saxony and Hamburg created laws on prisons, incorporating provisions on youth prisons, within the timescale required for the latter by the Federal Constitutional Court. Hesse passed its own law on adult prisons in 2010. All the remaining Länder, with the exception of North-Rhine Westphalia, were part of a working group to create a Musterentwurf (or model law), published in 2011, although so far this has only resulted in legislation being passed in Rhineland-Palatinate, the Saarland, Brandenburg, Saxony, and Mecklenburg Lower Pomerania. So, even eight years after the reform, the old Federal Prisons Law is still in force in six Länder, including the largest, North-Rhine Westphalia. ${ }^{49}$

As in the case of youth justice, there are variations on a number of questions perceived by politicians to be of 'symbolic' importance, and these are discussed briefly below (again based on our analysis of the laws). However, it is also striking that there are very substantial areas of similarity between the new laws (and indeed between these and the old Federal Prisons Law).

Aims of punishment: As in the case of youth prisons, there is some variation in the definition of the aims of punishment. Bavaria and Baden-Württemberg mention the protection of the community first (and only then resocialisation of offenders); the Musterentwurf (and those laws upon which it is based) put resocialisation first, and then mentions that protection of the community is also a function of prison; a similar formulation is adopted by Lower Saxony. Hamburg does the same, but emphasises the equal importance of this function to resocialisation.

Open and closed prisons: Again, there are similarities to the situation with youth prisons in whether a Land regards open or closed prison as the 'normal' form of punishment. Bavaria and Lower Saxony both make closed prison the norm, though

\footnotetext{
${ }^{48}$ F. Dünkel / J. Kühl, 'Neuregelung des Strafvollzugs in Hamburg', Neue Kriminalpolitik 21 (3/2009), pp. 82-6.

${ }^{49}$ Handbuch Strafvollzug der Länder; Schneider, Der neue deutsche Bundesstaat, pp. 224-5.
} 
in the latter case a prisoner 'should' be transferred to an open prison if certain criteria are met; Hesse views open prison as a relaxation of prison conditions (away from the 'default option' of closed prison); while all the other laws passed, the Musterentwurf, and the old Federal Prisons Law do not mention a particular 'default', but state that a prisoner 'should' be housed in an open prison if he or she meets certain conditions.

While the wording of the law might be of symbolic importance, the differences do appear to reflect differing attitudes to open prison. Bavaria, for instance, has had the lowest proportion of prisoners in open prisons throughout the 1990s and 2000s (8.1\% in 2009, compared to an average for the western Länder of 18.5\%). In Hesse, the proportion is $9.5 \%$ - though in 1996 it was $27.3 \%$, before the Land swung to the right politically, with the election of a hardline, CDU-led government. Of the Länder with a more harshly-worded law, only Lower Saxony confounds expectations, with $20.8 \%$ in open prisons in 2009 , just above the average..$^{50}$ Equally, the presence of such wide variation between the Länder reminds us that variation in prisons policy existed prior to the federalism reform of 2006.

Breaks from imprisonment for those serving life sentences: One topic mentioned in interviews, and which attained a certain media profile, was the stage at which inmates serving life sentences would be considered for a break from imprisonment. Most prisoners, according to the laws of each Land, can be considered for this, but under the Federal Prisons Law this could not be considered within the first ten years of a sentence for those serving a life term; this was adopted by Hesse, Bavaria, Baden-Württemberg, Lower Saxony and Hamburg. The Musterentwurf reduced this to five years, but this was one of just two proposals from civil servants which failed to find favour with politicians: in Rhineland-Palatinate, the Saarland, Saxony and Mecklenburg Lower Pomerania, politicians chose to stick with the ten-year rule. Only in Brandenburg - with its Justice Minister from the Left Party - did the decision differ, with no particular stipulation beyond the prison authorities considering it appropriate.

Duty to work: The other area where civil servants working on the Musterentwurf differed from leading politicians was in whether prisoners should be face a duty to undertake work. The duty was a feature of the Federal Prisons Law, and also the five laws passed by CDU / CSU-led Länder. However, the Musterentwurf proposed dispensing with it: in Rhineland-Palatinate, Brandenburg, and Saxony, this advice was followed; in Mecklenburg Lower Pomerania, the duty was retained, while in the Saarland, the 'duty' was abolished, but instead prisoners could be 'compelled' to work. Opponents of the duty to work argued that the European Court of Human Rights saw work as a reward for good behaviour and that it should not be used as a punishment; moreover, in practice there was a shortage of work so it was rarely refused, and indeed it was considered less challenging than undertaking therapy. ${ }^{51}$ Supporters of the duty to work pointed to its value in achieving resocialisation, and also the need to retain the infrastructure of prison employment (which would be lost,

\footnotetext{
${ }^{50}$ F. Dünkel / B. Geng / C. Morgenstern, 'Strafvollzug in Deutschland: Aktuelle rechtstatsächliche Befunde', Forum Strafvollzug (1/2010) pp. 20-32, here p. 29.

${ }^{51}$ Interview with civil servant, $5^{\text {th }}$ November 2012; 'Pro und Contra Arbeitspflicht', Forum Strafvollzug (4/2012), pp. 223-4.
} 
they argued, if the duty was deleted, as states would choose to save money by not providing employment for the prisoners with the least experience of work). ${ }^{52}$

Participation: The old Federal Prisons Law (paragraph 160) stated that it 'should' be made possible for prisoners to 'take responsibility for issues of common concern'. There was some legal debate about the extent to which this required prisons to establish some sort of representative body. In Hesse, Lower Saxony, the Musterentwurf and those laws based upon it, there is now reference to a representative body, but it remains on that basis that one 'should' be established, rather than a firm legal requirement. Only in Hamburg's law is the requirement to allow prisoners to take some responsibility binding. In Lower Saxony and the Musterentwurf (and laws based upon it), the prison authorities should discuss proposals coming from prisoners through this route, whereas in Bavaria and Hesse, prisoners are just entitled to put forward their points. ${ }^{53}$

In summary, then, legislation on adult prisons demonstrates, first, that the majority of Länder have been in no rush at all to deviate from the old federal law and plough their own furrow - with such enthusiasm only being detected amongst some Christian Democrat-led Länder. It is particularly striking that North Rhine Westphalia, the largest Land, has not yet passed its own law on adult prisons. Moreover, ten Länder chose to cooperate on a new law, through the Musterentwurf process, preferring a process of harmonisation (led by civil servants) to differentiation. Secondly, there are, nonetheless, still some differences, but these appear to be concentrated to a significant degree on issues of symbolic importance, such as the aims of punishment, the status accorded to open prisons, and the duty to work. While there are variations in Germany in the availability of work in prisons, and in particular in the proportion of prisoners accommodated in open prisons, these existed before the different legislation. Finally, some commentators have regretted the extent to which the new laws are vague in terms of personnel and structural requirements for prisons, so that potential improvements will be 'torpedoed by restrictive budgets'. ${ }^{54}$

\section{Investigative detention}

The lack of appetite for variation in laws across the territory is particularly striking when laws on investigative detention (Untersuchungshaft) are considered. As with youth justice, the Federal Constitutional Court required the Länder to produce laws. Lower Saxony included this area in its wider prisons law of 2007; 12 Länder formed a group to create a Musterentwurf, and while the remaining four Länder (Bavaria, Baden-Württemberg, Lower Saxony and North-Rhine Westphalia) were not part of this process, in practice their laws were quite similar. Certainly, the laws are similar in format, and indeed Schneider contends that 'there are no differences worth

\footnotetext{
52 'Pro und Contra Arbeitspfllicht', interview with trade union official, $4^{\text {th }}$ December 2013; interview with trade union official, $6^{\text {th }}$ January 2013.

${ }^{53}$ F. Drohsel, 'Interessenvertretung von Gefangenen - ein vernachlässigter Baustein der Strafvollzugsreform', Forum Strafvollzug (5/2012), pp. 293-8.

54 Ziethener Kreis, 'Neue Strafvollzugsgesetze: Nur gut gemeint reicht nicht!', Neue Kriminalpolitik (3/2012), pp. 85-6, here p. 86; also K. Drenkhahn, 'Was bringt der Musterentwurf zum Landesstrafvollzugsgesetz?', Forum Strafvollzug (5/2011), p. 266.
} 
mentioning'. ${ }^{55}$ Feest and Pollähne point to a few areas of divergence, such as pocket money and length of visits (where Lower Saxony's law is more restrictive than those elsewhere), although their greater concern is with legal uncertainty about the boundaries to Land competencies (since the federal government retains some responsibility for possible reasons for incarceration). ${ }^{56}$

\section{Conclusion}

At the time of the federalism reform, the shift in responsibility for prisons law was the source of surprise and consternation in equal measure: surprise, because it had not been seen as a major demand of the Länder, and consternation, because there were substantial anxieties about a 'race to the bottom', with a 'battle for the harshest punishment' being waged by Land politicians. There were also concerns about an apparent injustice, whereby prisoners in different Länder convicted of the same crime would be treated differently.

There are several clear messages which emerge from our findings. First, there has been no race to the bottom, in spite of fears to the contrary. Not only is this broadly confirmed by our empirical findings in the foregoing chapter, but it was accepted by every single practitioner we spoke to in the field, ${ }^{57}$ and even by some of the experts who had been most critical of the proposals. For instance, scholar Johannes Feest, while remaining critical, entitled an essay on the Musterentwurf on adult prisons 'A Musterentwurf not without value', which concludes:

'If [the law] is consistently implemented by the Länder and is not watered down by amendments and restrictive administrative decisions, then the fears at the time of the federalism reform of a "dog's dinner" and a "competition of harshness" will have, at least in part, have been banished. The Musterentwurf is admittedly miles away from the big hopes of a prison reform. But times are apparently such that one is happy when things don't turn out quite as badly as feared. ${ }^{58}$

In a similar vein, Frieder Dünkel (one-time author of an essay entitled 'The farce of the federalism reform' ${ }^{59}$ ) and his collaborators conclude that 'The initially feared "competition of harshness" has not happened so far, on the contrary, some Länder have made substantial investments, above all in youth prisons and therapy', and even refer to a 'competition for best practice'. 60

\footnotetext{
55 Schneider, Der Neue Deutsche Bundesstaat, p. 277.

${ }^{56}$ J. Feest / H. Pollähne, 'Haftgründe und Abgründe: Eine Zwischenbilanz zur Untersuchungshaftgesetzgebung', Forum Strafvollzug (1/2009), pp. 30-32.

${ }^{57}$ E.g. interview with trade union official, $4^{\text {th }}$ December 2013 ; interview with civil servant, $5^{\text {th }}$ November 2012 ; interview with civil servant, $31^{\text {st }}$ October 2012; interview with civil servants, interview with Land politicians, $7^{\text {th }}$ November 2012.

${ }^{58}$ J. Feest, 'Ein Musterentwurf nicht ohne Wert. Anmerkungen zum ME StVollzG1 vom Autorenkreis des AK StVollzG2', Neue Kriminalpolitik (1/2012), pp. 5-8, here p.8.

${ }^{59}$ Dünkel, Frieder (2007): Die Farce der Föderalismusreform: Ein Vergleich der vorliegenden Gesetze und Gesetzesentwürfe zum Jugendstrafvollzug, Greifswald University Working Paper, available at http://www.rsf.uni-greifswald.de/fileadmin/mediapool/lehrstuehle/duenkel/Stand_JuVoG_24_9_2007.pdf .

${ }^{60}$ F. Dünkel et al. 'Strafvollzug in Deutschland' p. 31.
} 
Secondly, we see substantial differences between the Länder in their appetite for variation in this policy area. While a few - Bavaria, Baden-Württemberg, Hamburg, Hesse, and Lower Saxony (at the time, all led by Christian Democrats) were keen to legislate autonomously, others have been far keener to collaborate with other Länder, with joint drafts of legislation. This should, perhaps, not be a surprise, given the shared disdain for decentralisation of the legislative responsibility amongst many civil servants and politicians, as well as the relatively tight parameters set on prison laws by both the Basic Law and verdicts of the Federal Constitutional Court. It is also striking that in the area of adult prisons, several Länder, including the largest (North-Rhine Westphalia) are still relying on the old federal legislation eight years on, and have not passed their own law.

Thirdly, where differences between the laws are observed, quite often they appear to be around issues of symbolism, possibly affecting relatively few prisoners, such as the aims of punishment, or whether open or closed prison is, in legal terms, regarded as the default. Here, some Christian Democrat politicians - in government and in some Länder in opposition - sought to emphasise their conservative values, although this desire was not universally shared: several CDU-led Länder adopted the Musterentwurf on youth prisons with little modification, for instance. There are occasional variations due to Land context - particularly evident, for instance, in Baden-Württemberg's youth prisons law, and there is modest evidence, too, of other Länder seeking to learn from this experience. There is also some evidence of Land politicians taking a greater interest in this policy area, and being willing to invest extra funds as a result. ${ }^{61}$

Fourth, the federalism reform did ensure that Länder were able to legislate in areas which, hitherto, had been left untouched due to a stand-off between the federal government and the Bundesrat: indeed, if, as suggested in the introduction, reducing the number of veto players in this policy area to facilitate legislation was behind the transfer of responsibility, it has been a success, with laws being passed in all areas demanded by the Federal Constitutional Court, but also in the area of adult prisons in several Länder after an impasse spanning decades at the federal level.

Fifth, there were some suggestions that the federalism reform had made it harder, rather than easier, for Länder to co-operate. A senior prison trade union official expressed frustration at the costly failure of Länder to cooperate, giving the examples of Berlin's refusal to cooperate with Brandenburg on part of the youth prisons estate, and a failed plan to co-operate on youth prisons between Saxony, Saxony-Anhalt and Thuringia, and took the view that 'German (prison) federalism is a synonym for burning money'!62

There is a final, crucially important, conclusion, which points to the limits of this study. While we have examined prison laws, and found substantial areas of similarity, it is clear that in such areas as the proportion of prisoners in open vs. closed prisons, levels of staffing, occupancy levels, and levels of expenditure per prisoner, there are still wide variations between the Länder, and thus the 'injustice' if it is one - of prisoners being treated differently across the territory, is real. This

\footnotetext{
${ }^{61}$ Interview with civil servant, $5^{\text {th }}$ November 2012; interview with civil servants, $4^{\text {th }}$ December 2012.

${ }^{62}$ Interview with trade union official, $4^{\text {th }}$ December 2013.
} 
happened before the federalism reform, but differentiation between the laws may well legitimate and entrench such differences.

Our analysis of prisons law in Germany since 2006 has, therefore, called into question bold claims about the impact of decentralisation, which see inevitable 'races to the bottom', or indeed wide scope for experimentation and policy learning. Instead, two key points emerge. On the one hand, it was widely feared that there would be a 'race to the bottom' in prisons law if the competence was passed to the Länder, and that has not happened. Instead, there has been a high level of coordination between most Länder, with some divergence driven by context and, in particular, differences in party politics. The appetite to take advantage of the new ability to legislate also varied widely, with a few Länder far more interested than the rest.

On the other hand, there is substantial variation in the way prisoners are treated depending upon which of the Länder they are incarcerated in, and so one of the premises of this collection - that it is important to look at politics and policy below the national level - is still confirmed. This variation predated the federalism reform of 2006, and stemmed from administrative decisions, as well as differences in infrastructure and budget, at the level of the Länder. It is thus an important reminder that if only legislation, and not policy implementation, is the object of analysis, important variation in policies may be neglected - a point which could apply just as much to unitary as to federal states. 